\title{
OLAH RAGA DAN POLA TIDUR BERHUBUNGAN DENGAN KEJADIAN PREMENSTRUAL SYNDROME (PMS)
}

\author{
Lisnawati \\ Jurusan Kebidanan Poltekkes Kemenkes Tasikmalaya \\ e-mail : bidan_lisna85@yahoo.com
}

\begin{abstract}
PMS are a set of physical, emotional, and behavioral complaints and symptoms that occur in reproductive women which appear cycles around 7-10 days before menstruation and disappears after menstrual blood comes out at a level that is capable of affecting lifestyle and activity. The aim of this research is to know the relationship of exercises and sleeping patterns with the occurrence of PMS at Cirebon Midwifery Student Program. This research is a kind of observational analytic research with cross sectional approach. The population is all female students of Cirebon Midwifery Study Program by purposive sampling, total 141 sample of people taken. The instrument used is the Shortened Premenstrual Assessment Form (SPAF) questionnaire. Data analysis using chi-square. The results of the study showed that most respondents did not exercise regularly (68.8\%), most of them had poor sleep patterns (66\%), most of them had moderate to severe of PMS (68.8\%). Data analysis shows that exercises and sleep patterns have a relationship with PMS events.
\end{abstract}

Keywords: exercises, sleep patterns, Pre-Menstrual Syndrome (PMS)

\begin{abstract}
ABSTRAK
Pra Menstrual Syndrome (PMS) adalah sekumpulan keluhan dan gejala fisik, emosional, dan perilaku yang terjadi pada wanita reproduksi, yang muncul secara siklus dalam rentang waktu 7-10 hari sebelum menstruasi dan menghilang setelah darah haid keluar yang terjadi pada suatu tingkatan yang mampu mempengaruhi gaya hidup dan aktivitas. Penelitian bertujuan untuk mengetahui hubungan olah raga dan pola tidur dengan kejadian PMS pada Mahasiswi Program Studi Kebidanan Cirebon. Penelitian ini merupakan jenis penelitian observasional analitik dengan pendekatan cross sectional. Populasi adalah semua mahasiswi Program Studi Kebidanan Cirebon dengan jumlah sampel 141 orang, diambil dengan cara purposive sampling. Instrumen yang digunakan adalah kuesioner Shortened Premenstrual Assessment Form (SPAF).Analisa data dengan menggunakan chi-square. Hasil penelitian menunjukan sebagian besar responden tidak rutin dalam melakukan olahraga $(68,8 \%)$, sebagian besar responden mempunyai pola tidur yang buruk $(66 \%)$,sebagian besar responden mengalami gejala PMS sedang sampai dengan berat $(68,8 \%)$. Analisa data meunjukkan bahwa olah raga dan pola tidur memiliki hubungan dengan kejadian PMS.
\end{abstract}

Kata Kunci : olah raga, pola tidur, Premenstrual Syndrome (PMS) 


\section{PENDAHULUAN}

Kesehatan remaja menjadi fokus perhatian karena jumlah remaja yang cukup besar. Salah satu masalah kesehatan tersebut yaitu Premenstrual Syndrome (PMS). PMS adalah kombinasi gejala yang terjadi sebelum menstruasi dan menghilang dengan keluarnya darah menstruasi, serta dialami oleh banyak wanita sebelum awitan setiap siklus menstruasi (Damayanti, 2013). American College of Obstetricians and Gynecologist) menyatakan bahwa sedikitnya $85 \%$ dari wanita menstruasi mengalami minimal satu dari gejala PMS dan umumnya terjadi pada wanita usia 14 - 50 tahun dengan gejala yang bervariasi dan berubah - ubah pada tiap wanita setiap bulannya.(Saryono, 2009).

Penelitian Essel (2007) melaporkan 23\% wanita Indonesia mengalami PMS dan dari hasil penelitian lainnya dari 260 orang wanita usia subur, ditemukan sebanyak 95\% memiliki setidaknya satu gejala PMS dengan tingkat PMS sedang hingga berat sebesar 3,9\%. Prevalensi PMS di beberapa daerah di Indonesia bervariasi antara $25 \%$ sampai $45 \%$ (Putri, 2013). Penyebab PMS belum diketahui pasti akan tetapi berdasarkan teori dari berbagai penelitian PMS kemungkinan bisa disebabkan oleh faktor-faktor hormonal, kekurangan vitamin-vitamin tertentu, faktor lingkungan, dan keadaan psikologi. Secara fisiologis maka saat fase luteal siklus menstruasi akan terjadi ketidakseimbangan rasio hormon estrogen dan progesteron, di mana estrogen akan menekan progesteron yang menyebabkan gejala fisik berupa retensi natrium, retensi cairan dan edema, serta gejala-gejala fisik lain (Brunner \& Suddarth, 2001 dalam Maulana, 2008).

Olahraga memiliki pengaruh terhadap terjadinya PMS, karena olahraga merupakan aktivitas fisik yang dapat memperbaiki aliran darah dan pelepasan hormon endhorphin, apabila seseorang tidak melakukan olahraga dapat berpengaruh terhadap tingkat gejala PMS(Holmes dkk., 2010 dalam Arantika Meidya Pratiwi 2014). Tidak sependapat dengan Damayanti (2013) yang mnenyatakan bahwa tidak terdapat hubungan antara olahraga dengan kejadian PMS(Bakker,etc.2007;Brunner, Suddart.2001). 
Pola tidur merupakan salah satu faktor yang berhubungan dengan PMS, dimana pola tidur yang baik dapat memperingan terjadinya gejala PMS.Baik atau buruknya pola tidur dapat mempengaruhi sekresi berbagai hormon yang ada dalam tubuh (Shecterdan Boivin, 2010 dalam Kartikasari,I. 2015). Sesuai dengan Bakker, dkk(2010) bahwa pola tidur tidak baik akan meningatkan keparahan dari gejala PMS.

Berdasarkan survei pendahuluan yang dilakukan pada mahasiswi Program Studi DIV Kebidanan Cirebon Tahun Akademik 2016/2017, dari 37 mahasiswi terdapat 20 mahasiswi (54\%) yang mengalami PMS dan dirasakan sangat mengganggu kegiatan belajar ataupun aktivitas lain.

\section{METODE PENELITIAN}

Penelitian ini menggunakan desain penelitian observasional analitik dengan pendekatan cross sectional. Jumlah sampel sebanyak 141 orang mahasiswi, yang diambil dengan menggunakan teknik purposive sampling. Variabel olah raga dan pola tidur menggunakan kuesioner (12 pertanyaan) yang diisi oleh responden.
Data PMS diperoleh dari hasil pengisian Shortened Premenstrual Assessment Form $(S P A F)$ oleh responden. Kuesioner ini merupakan ringkasan dari Premenstrual Assessment Form (PAF) yang terdiri dari 95 pertanyaan (Allen dkk., 1991). SPAF merupakan kuesioner yang sudah dibakukan bersifat tetap dan sudah dan sudah teruji validitas dan reabilitasnya (Allen dkk., 1991). Dimana berdasarkan penelitian yang dilakukan di korea, diketahui bahwa keandalan dari kuesioner ini adalah 0,80 konsistensi internal (croanbach alpha) adalah 0,91 dan korelasi antara coeffeciency score adalah 0,92 (Lee dkk.,2002). Disamping itu instrumen ini juga sudah digunakan oleh berbagai penelitian PMS diluar maupun didalam Negeri dan masih di gunakan sampai sekarang(Kartiksari,2014; Karaman , dkk.2012).Analisa data dengan menggunakan chi square.

\section{HASIL}

\section{Karakteristik responden berdasarkan Kebiasaan Olahraga}

Berdasarkan Tabel 1 diketahui bahwa sebagian besar responden tidak rutin melakukan olahraga yakni sebanyak 97 orang $(68,8 \%)$. 
Jurnal Care Vol .5, No2,Tahun 2017

Tabel 1. Distribusi Frekuensi Responden Berdasar Kebiasaan Olahraga di Prodi DIV Kebidanan Cirebon

\begin{tabular}{lcc}
\hline Kategori & Jumlah & $\%$ \\
Olahraga & & \\
Rutin & 44 & 31,2 \\
Tidak rutin & 97 & 68,8 \\
\hline Total & 141 & 100 \\
\hline
\end{tabular}

Tabel 2. Distribusi Frekuensi Responden Berdasar Pola Tidur di Prodi DIV Kebidanan Cirebon

\begin{tabular}{lcc}
\hline $\begin{array}{l}\text { Kategori } \\
\text { Pola Tidur }\end{array}$ & Jumlah & $\%$ \\
\hline Baik & 48 & 34 \\
Buruk & 93 & 66 \\
\hline Total & 141 & 100 \\
\hline
\end{tabular}

Berdasarkan Tabel 2 diketahui bahwa sebagian besar responden mempunyai pola tidur yang buruk, yakni 93 orang $(66 \%)$.
Berdasarkan Tabel 3 diketahui bahwa sebagian besar responden mengalami kejadian PMS dengan kategori gejala sedang hingga berat yakni 97 orang $(68,8 \%)$.

Tabel 3. Distribusi Frekuensi Responden Berdasar Kejadian PMS di Prodi DIV Kebidanan Cirebon

\begin{tabular}{lcc}
\hline Kategori PMS & Jumlah & $\%$ \\
\hline $\begin{array}{l}\text { Tidak ada gejala } \\
\text { hingga ringan }\end{array}$ & 44 & 31,2 \\
$\begin{array}{l}\text { Gejala sedang } \\
\text { hingga berat }\end{array}$ & 97 & 68,8 \\
\hline Total & 141 & 100 \\
\hline
\end{tabular}

Uji statistik dengan menggunakan uji Chisquare diperoleh nilai @ value sebesar 0,00. Karena $\varrho$ value $\leq \alpha$, sehingga keputusannya $\mathrm{H}_{0}$ ditolak, artinya terdapat hubungan antara Olahraga dengan kejadian PMS

\section{Hubungan Olahraga dengan Kejadian PMS}

Tabel 4. Hubungan Olahraga dengan Kejadian PMS Mahasiswi di Prodi DIV Kebidanan Cirebon

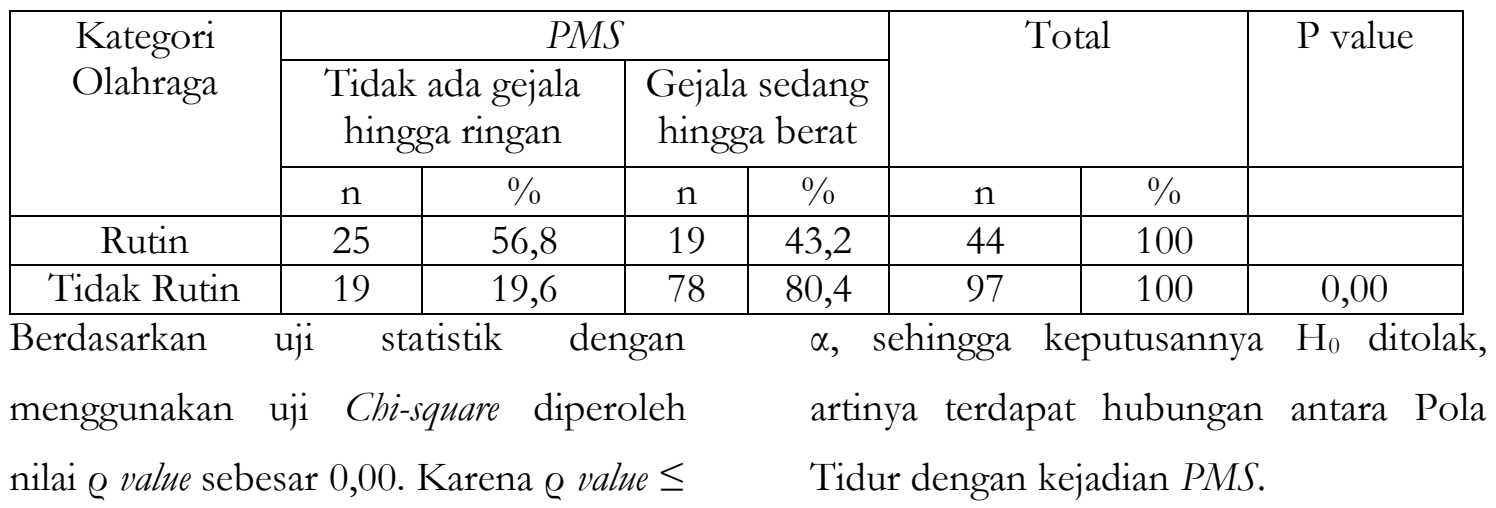


Jurnal Care Vol .5, No2,Tahun 2017

\section{Hubungan Pola Tidur dengan Kejadian PMS}

Tabel 4. Hubungan Pola Tidur dengan Kejadian PMS Mahasiswi di Prodi DIV Kebidanan Cirebon

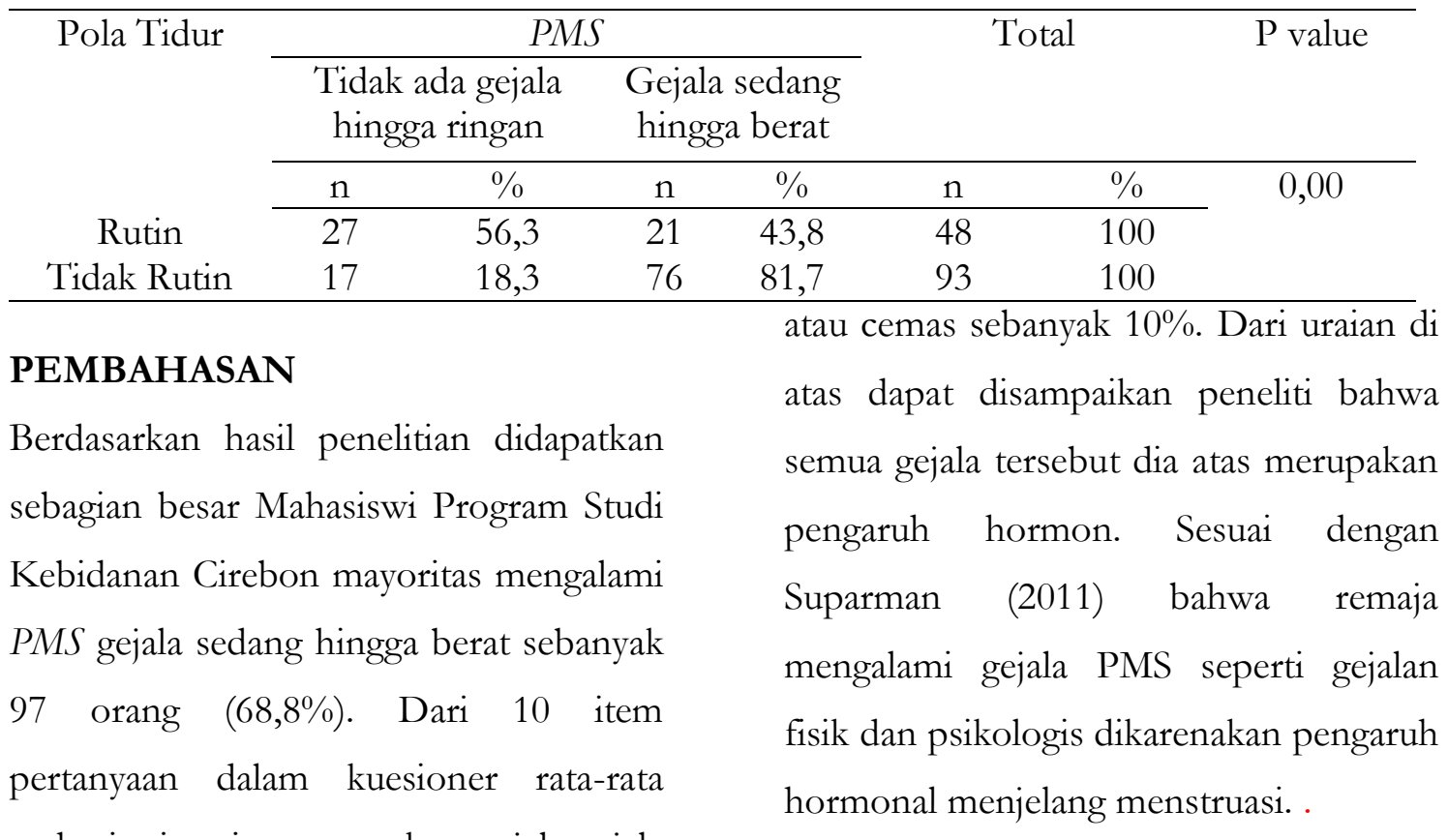

mahasiswi sering merasakan gejala-gejala PMS setiap bulannya baik fisik maupun psikologis seperti gejala fisik dari 5 pertanyaan yang sering dirasakan yaitu, perut merasa tidak nyaman pada saat akan menstruasi dialami oleh mahasiswi sebanyak 24\%, payudara terasa nyeri pada saat ditekan atau tanpa ditekan, dan terjadi pembesaran menjelang menstruasi dirasakan sebanyak $22 \%$, sakit punggung, sendi dan otot dirasakan sebanyak $16 \%$, sedangkan gejala psikologis dari 5 pertanyaan rata-rata mengalami gejala seperti sensitive terhadap penolakan, mudah menangis, tersinggung sebanyak $28 \%$, merasa dibawah tekanan tertekan

\section{Hubungan Olah Raga dengan Kejadian PMS}

Sebagian besar mahasiswi Program Studi Kebidanan Cirebon tidak rutin dalam melakukan olahraga. Banyak mahasisiwi yang mengatakan tidak rutinnya olahraga karena rutinitas yang banyak setiap hari nya jadi terkadang lupa atau malas melakukan olahraga.

Hasil penelitian aktivitas olahraga didapatkan hasil bahwa 44,4\% responden berolahraga secara rutin dan 68,8\% berolahraga tidak rutin. Pada kelompok responden yang berolahraga rutin 
menyatakan bahwa tidak ada gejala hingga gejala ringan 56,8\% sedangkan kelompok olahraga yang tidak rutin mengalami PMS sedang hingga berat yakni 80,4\%. Berdasarkan hasil uji Chisquare diperoleh @value 0,00 (<0,05), menunjukan bahwa $\mathrm{H}_{0}$ ditolak atau hipotesis penelitian diterima yaitu ada hubungan antara olahraga dengan kejadian PMS. Artinya mahasiswi yang tidak rutin melakukan olahraga akan cenderung mengalami gejala PMS lebih banyak dibandingkan yang melakukan olahraga rutin. Hal ini sesuai tinjauan teori menurut Saryono dan Sejati (2009) yang menyatakan bahwa pada sebagian besar wanita, olahraga mampu mengurangi gejala PMS yaitu mengurangi kelelahan, stres dan meningkatkan kesehatan tubuh.

Olahraga meningkatkan rangsang simpatis, yaitu suatu kondisi yang menurunkan detak jantung dan mengurangi sensasi cemas sehingga responden yang berolahraga rutin dapat mengurangi gejala-gejala PMS. Banyaknya rutinitas serta tugas yang dikerjakan setiap harinya oleh mahasisiwi kebidanan membuat mahasiswi mengabaikan pola olahraga yang rutin setiap minggunya sehingga banyak mahasiswi yang cenderung mengalami PMS sedang sampai berat. Selain itu ditambah dengan waktu olahraga rutin yang tidak ideal dalam melakukan olahraga (Maulana,R.2008).Sesuai dengan Saryono et al (2008) menyatakan bahwa olahraga sangat berpengaruh terhadap terjadinya PMS, karena dengan olahraga rutin dan berkelanjutan dapat terjadi peregangan otot-otot sehingga melancarkan aliran darah dan pelepasan Endhophinkarena hormon Endhophin memacu rasa rilek. Hal ini membuktikan olahraga yang teratur mencegah dan mengurangi PMS karena apabila tidak melakukan olahraga rutin hormon estrogen akan lebih tinggi sehingga kemungikinan akan terjadi PMS lebih besar.

Penelitian ini sesuai dengan dengan penelitian yang dilakukan oleh Pratiwi (2012) terhadap mahasisiwi Program Studi DIV Pendidik Fakultas Kedokteran Universitas sebelas Maret Surakarta yang menyatakan bahwa ada hubungan yang bermakna antara olahraga dengan kejadian PMS dengan nilai $\mathrm{P}$ value $=0,00$. 
Jurnal Care Vol .5, No2,Tahun 2017

\section{Hubungan Pola tidur dengan kejadian PMS}

Sebagian besar mahasiswi Program

Studi Kebidanan Cirebon memiliki pola tidur yang buruk. Hal tersebut dilihat dari komponen utama dalam kuesioner seperti pada kualitas tidur buruk sebanyak $22 \%$, letensi tidur (kesulitan memulai tidur) sebanyak 16\%, gangguan tidur sebanyak $32 \%$, penggunaan obat tidur $6 \%$, dan gangguan aktivitas disiang hari sebanyak 24\%. Dikatakan pola tidur buruk karena rata-rata mahasiswi memiliki kualitas tidur yang kurang baik , seperti kebiasaan tidur larut malam. Dari hasil wawancara dengan responden disampaikan bahwa mereka sulit tidur (insomnia) dan membutuhkan waktu yang lama untuk merasakan tidur yang lelap \pm 2 jam, selain itu pada saat sedang melakukan praktik di RS atau Puskesmas sering kali tidak tidur, sehingga pola tidur tidak terjadwal dengan baik. Rata-rata mahasiswi memiliki durasi tidur 5-6 jam.

Sering kali juga terjadi pada saat tidur terbangun karena ingin ke toilet, mengalami mimpi buruk 2-3 kali dalam seminggu. Kejadian tersebut di atas disebabkan karena tidur yang tidak tenang, sedang mengalami stres, sehingga tidur sering merasa terganggu, dan tibatiba terbangun ditengah malam, dan kemudian sulit untuk tidur kembali, . Walaupun mahasiswi banyak yang mengalami masalah dalam pola tidur akan tetapi mereka tidak mengkonsumsi obatobatan yang dapat membantu untuk tidur karena adanya pengetahuan pada diri mereka bahwa dengan mengkonsumsi obat-obatan tersebut akan menjadi suatu kebiasaan yang tidak baik. Pola tidur yang buruk juga berpengaruh pada aktivitas disiang hari seperti banyaknya mahasiswi yang mengantuk pada saat belajar dikelas, menyetir, dan kegiatan lainnya.

Responden dengan pola tidur baik, menyatakan tidak ada gejala hingga hanya gejala PMS ringan ; sedangkan responden dengan pola tidur buruk, mayoritas responden mengalami PMS sedang hingga berat.

Berdasarkan hasil uji Chi-square diperoleh Qvalue $0,00(<0,05)$, yang menunjukan bahwa $\mathrm{H}_{0}$ ditolak atau hipotesis penelitian diterima yaitu ada hubungan antara pola tidur dengan kejadian PMS. Hasil penelitian ini sejalan dengan penelitian yang serupa dengan menggunakan 
kuesioner PSQI, menemukan bahwa PMS memiliki hubungan dengan pola tidur (Cheng dkk.,2013, dalam Karaman 2012). Dimana pola tidur yang baik (tidur tanpa gangguan) ternyata dapat meringankan gejala PMS. Artinya mahasiswi yang mengalami pola tidur tidak baik akan berpeluang mengalami gejala PMS baik sedang maupun berat.

Buruknya latensi tidur dan kualitas tidur pada mahasiswi kebidanan dapat disebabkan karena rutinitas yang berlebih (praktik lapangan, jadwal yang yang tidak banyak tugas). Selain itu juga dipengaruhi dari penggunaan media elektronik khusunya handphone. Sesuai dengan Meilani (2014) bahwa terdapat hubungan antara frekuensi penggunaan handphone dan durasi penggunaannya dengan kulitas tidur. Sesuai pula dengan teori Shechter dan Boivin (2010) bahwa tidur merupakan salah satu faktor yang memiliki keterkaitan dengan PMS, dimana pola tidur yang baik (tidur tanpa gangguan) ternyata dapat memperingan gejala $P M S$.

\section{KESIMPULAN}

1. Sebagian besar responden tidak rutin dalam melakukan olahraga $(68,8 \%)$

2. Sebagian besar responden mempunyai pola tidur yang buruk $(66 \%)$

3. Sebagian besar responden mengalami gejala PMS sedang sampai dengan berat $(68,8 \%)$.

4. Olah raga dan pola tidur memiliki hubungan dengan kejadian PMS

\section{Saran}

Penelitian ini dapat digunakan sebagai dasar untuk penelitian lebih lanjut tentang variabel lain yang mempengaruhi kejadian PMS dengan menggunakan teknik kualitiatif agar penggalian datanya lebih optimal.

\section{REFERENSI}

Allen, dkk.(1991). The Shortened Premenstrual Assessment Form. J Reprod Med, 36, 769-72.

Bakker ,F.C ., Kahan, T,L.,Trinder, J.dan Colrain, I. M.(2007). Sleep Quality And The Sleep Electroencephalogram In Women With Severe Premenstrual Syndrome of Journal .Sleep, 30, 1283- 
Brunner \& Suddarth. (2001). Buku Ajar Keperawatan Medikal Bedah, Jakarta: EGC.

Cheng, S. H,. Shih , C. C, Yang . Y. K,. Chen, K. T. Chang, Y. H. Dan Yang, Y. C. (2013). Factors Associated With Premenstrual Syndrome A survey of New Female University Students. Kaohsiung Journal Of Medical Sciences 29,6

Damayanti, S.(2013). Faktor -faktor yang berhubungan dengan Premenstrual Syndrome pada mahasiswa DIV Kebidanan di Sekolah Tinggi Ilmu Kesehatan U'budiyah Bunda. Jurnal Keperawatan.

Http://180.241122.205/Docti/SIT IDAMAYANTI-Skripsi-

Maya.Pdf.Diakses Pada Tanggal 0511-2016

Karaman H. I. O., Tanriverdi , G. Dan Degimenci , Y. (2012 ). Subjective Sleep Quality In Premenstrual Syndrome - Jurnal Gynecological Endocrinologi

Kartikasari,I. (2014) Faktor-faktor yang berhubungan dengan kejadian Premenstruasi Syndrome pada sisiwi SMA 112 Jakarta Tahun 2015. Jurnal Kebidanan
Lee ,dkk.(2002). The Standardization Of The Shortened Premenstrual Assessment Form And Applicability On The Internet . $J$ Korean Neuropsychiatr Assoc, 41, 8 Maulana, R. (2008). Hubungan Karakteristike Wanita Usia Produktif dengan Premenstrual Syndrome (PMS) di Poli Obstetri dan Gynekology RSUD dr. Zainoel Abidin Banda Aceh. Jurnal Kedokteran

Meilani.(2014). Pengarub Penggunaan Media Elektronik Terbadap Kualitas Tidur Siswa-Siswi SMA Santo Thomas I Medan. Skripsi , Universitas Sumatera Utara.

Pratiwi,A.M.(2014). Aktivitas Olahraga dengan Kejadian Sindrom Premenstruasi pada Anggota Perempuan UKM INKAI UNS Sekolah Tinggi Ilmu Kesehatan Alma Ata Yogyakarta Jalan Ringroad Barat Daya No 1 Tamantirto, Kasihan, Bantul Yogyakarta. Diakses pada tanggal 23-11-2016

Putri, R. P. D. P. (2013).Hubungan antara Derajat Sindrom Pramenstruasi dan Aktivitas Fisik dengan Perilaku Makan pada Remaja Putri. 
Universitas Diponegoro Semarang.

Diakses pada tanggal 14-11-2016

Saryono.(2009). Sindrom Pramenstruasi.

Pustaka Pembangunan Nusantara :

jakarta

Shechter, A. Dan Boivin, D . B .(2010).

Sleep, Hormones, and Cicardian

Rhythms throughout the Menstrual Cycle

in Healthy Women and Women With

Premnestrual Dysphoric Disorder .

International Journal of Endocrinology

2010:17

Suparman.(2011). Premenstrual Syndrome.

Jakarta: EGC 